\section{Patenas in Ceylon}

I REGRET that through an accident I was able only yesterday to read Mr. Heelis's reply to my letter on the subject of patenas in Ceylon. I have not a copy of my own letter by me and therefore cannot speak with certainty, but I believe that $I$ only suggested that the cropping out of the thick band of quartzite amongst the gneiss was sufficient to explain the existence of many of the larger patenas in the Kandyan Province. The immense majority of the smaller and more isolated patenas I am fully aware cannnot be explained on my supposition, nor can they at present be explained on any reasonable supposition. I do not think, however, that even the most superficial observer can have any doubt as to the large patena mentioned in my letter between Pussellawa and Rambodde, covering several thousands of acres, being entirely due to the quartzite band that lies above it. In regard to the Dimbula patenas it is no doubt true that gneiss is aimost always found underlying the soil, but this does not prove that the patena soil is derived from the gneiss. The depth of the rock below the surface is against this view, especially when taken in connection with the fact that $I$ was never able to trace in the case of patenas as I did in scores of cases of jungle land, in railway and road cuttings throughout the Kandyan Province, the gradual changes from the hard rock upwards to the surface, which show that the soil has been produced by the disintegration of the gneiss in situ. The denuding forces at work among these mountains are so excessive (according to an estirnate made by myself at Pussellawa the denudation was no less than ten inches in thirty years on land cleared for coffee) that strata probably of many thousands of feet in thickness have been carried away to the low country and the sea. It is not, it seems to me, at all an improbable supposition that in Dimbula and Ouvah a band of cuartzite has during this denudation been disintegrated, and that its remnants are found now in isolated places resting on the gruciss. The limestone mentioned by Mr. Ifeelis as occurring in the Ouvah patena district proves, I think, a point in my favour, for the same kind of limestone is more plentiful in the neighbourhood of the quartzite band between Pussellawa and Rambodde than in any other district with which $I$ am acequainted, there being no less than five entirely isolated spots near these villages where it occurs. This limestone is highly crystalline and of the same age as the gneiss, for $I$ have found it at the upper fall at Rambodde passing almost imperceptibly both above and below into the gneiss. It is here about 450 feet above the upper surface of the quartzite band, where it crops out in the lower fall. Its stratified character may be readily seen at Pussellawa by the bands of mica-fragments that run through it in almost horizontal directions. I have never heard of this limestone covering any extensive area except at Matalé, where there must be some hundreds of acres of it. In other localities that I have visited it covers only an acre or more frequently only a fraction of an acre. The soil produced by its disintegration is, I believe, the richest in the island, as is shown by the fact that the limestone after being burnt is frequently used as a manure for coffee trees, and that the jungle growing below such rocks is generally of the richest description. I can scarcely therefore think that any considerable area of patena soil in Ouvah is formed by the disintegration of limestone, although it is quite consistent with what occurs at Rambodde that limestone should be extensively found in the neighbourhood of a large patena. As to the quality of the soil on the Ouvah patenas the test yenerally applied by planters is that of the power of the coffee tree to produce fruit. This is manifestly not a perfect test. Climate counts for a great deal, and the climate of Ouvah is recognised as the most favourable in Ceylon for the production of coffee, whilst that of Dimbula is acknowledged to be too humid for the perfect fruiting of the plant. I remember a pertinent remark made to me by a successful planter in regard to the relative values of soil and climate in the growing of coffee. "Give me the climate and I can make the soil." It is an exaggeration, but there is sufficient truth in it to illustrate well the point I am urging.

Finally in regard to abandoned clearings falling back not into "chena" and jungle but into patena land, I must confess I never met with an instance of it, and with $\mathrm{Mr}$. Heelis' permission I would suggest that the Dimbula cricket ground is scarcely a case in point. It is probably the interest of the owner to keep it in grass and to prevent seeds accidentally carried to it from taking root. But supposing it were surrounded by forest and left to itself for twenty years, would it at the end of that period be still in grass, or would it have returned to "chena"? If it were ge nuine patena land, it would remain so, for plants accidentally imported into it would find no nourishment, but if it were impoverished jungle soil, I am inclined to the opinion that there would still be sufficient unextracted nourishment to enable at least the hardier species to grow in a stunted form until humus was deposited, when forest would succeed. Whilst differing from Mr. Heelis on the several points of his letter I cannot omit to thank him for the courtesy with which he has expressed his opinions.

Ouseburn, May Io

R. Alsuay

\section{The Greenland Seal Fishery}

Another year has passed and no steps have been taken to put some restriction upon the cruel and wasteful manner in which the seal fishery is prosecuted. Warning after warning has been given, and still nothing has been done. In 1868 Dr. Brown wrote (Proc. Zool. Soc., p. 440) : "Supposing the sealing prosecuted with the same vigour as at present, I have little hesitation in stating my opinion that, before thirty years shall have passed away the seal-fishery, as a source of commercial rcvenue, will have come to a close." This season the Dundee vessels have been turning their attention to the Newfoundland seals, for, says a paragraph in the Daily New's, "Capt. Adams has for some years been of opinion that that ground [the Greenland sealfishery] is practically used up, and hence his visit to Newfoundland." The small success of the Greenland sealers this season fully corroborates Capt. Adams's opinion, and forms a practical comment upon Dr. Brown's prediction!

From the same source (Daily Nivs) I learn that "advices of a very gratifying character have been received from Newfounc. land. The Pantier has taken 20,000 seals, the Neptune 30,000, the Aictic 24,000, the Aurora 15,000, and high expectations have been formed regarding the success of the whole fleet. These four vessels have secured 89,000 seals; Capt. Gray says 20 per cent. may be added to the number of seals actually taken for those mortally wounded and lost, and that as these are breeding seals each old one will leave a young one to die of starvation. (See letter in Land and W'ater, May 9, 1874.) The result will be that these four vessels destroyed 2 I3, coo seals! Similarly "gratifying" advices have been received from the other vessels of the fleet.

If the Royal Society for Prevention of Cruelty to Animals and the anti-vivisection advocates really 'wish to do service in the cause of humanity, let them reprint Capt. Gray's letter and distribute it broadcast, nor let them cease their efforts till a proper close time is obtained for these persecuted animals. Apart from all questions of humanity, common prudence would dictate that so rich a source of revenue, which, if properly cared for, may last an indefinite period, should be secured from the rapacity of those who will otherwise soon bring about its extinction. Now is the time for considering the steps which should be taken to bring the matter before the Governments concerned; if left till later in the year hasty legislation will probably, as in the last attempt, end in failure.

Norwich

THOMAS SOUTHWELL

\section{A New Lecture Experiment for Proving the Compound Nature of White Light}

THE old method of showing the compound nature of light by the composition of artificial colours on the lecture-table, is to arrange the various colours in the proper proportion on a disc and to revolve this disc rapidly; but a pure white cannot be produced by this method since there is necessarily a partial absorp: tion of rays on every part of the disc.

My method is to arrange seven lanterns, in the first place, so as to project their several circles of light side by side on a white screen, then to colour each circle by introducing slides of glass stained to imitate the seven colours of the spectrum (the proper intensity of colour being found by trial); we thus get seven circles on the screen coloured from red to violet and arranged side by side. Then by turning the several lanterns so that the projected circles shall exactly overlap each other we get one circle of white light, proving that the seven colours together make white light.

The same effect can be produced with five colours only if properly selected; and even two, the ordinary cobalt blue and deep 